\title{
Ways to reduce adverse effects of stress in pigs using nutritional factors
}

\author{
N.V. Bogolyubova ${ }^{1}$, M.G. Chabaev ${ }^{1}$, Yu.P. Fomichev ${ }^{1}$, E.Yu. Tsis ${ }^{1}$, A.A. Semenova ${ }^{2}$, \\ R.V. Nekrasov ${ }^{1 *}$ \\ ${ }^{1}$ L.K. Ernst Federal Science Center for Animal Husbandry \\ Dubrovitsy 60, Podolsk Municipal District, Moscow Region, 142132 Russia. \\ ${ }^{2}$ V.M. Gorbatov Federal Research Center for Food Systems of Russian Academy of Science \\ Talalikhina str. 26, Moscow, 109316 Russia. \\ Tel/Fax:+7(4967)651277, E-mail: nek roman@mail.ru \\ Received: 15.05.2019. Accepted: 19.06.2019
}

\begin{abstract}
Modern intensive technologies for handling and growing highly productive animals are accompanied by significant changes in their homeostasis causing stress and adversely affecting their health and the quality of the products obtained from them. Depending on the cause, stress is classified as social (technological), environmental, dietary, and immunological. Various types of stress adversely affect the body and contribute to endocrine, energy balance, and carbohydrate-lipid metabolism disturbances, which adversely affects the animal resistance to diseases, productivity and reproductive characteristics. Stress leads to metabolic disorders and changes in the ratio of muscle and fatty tissues. Every year, the manifestations of antemortem and postmortem pathological changes in the microstructure of animal muscle tissue are increasingly noted. Moreover, the affected structures of muscle fibers are characterized by hyper contraction, disruption of cell membranes, and formation of extracellular protein substance represented by denatured forms of proteins reducing the nutritional value and consumer characteristics of the final product. The use of antioxidants in pig diets, including natural ones, helps to reduce the impact of environmental stress factors on animals and increase their adaptive capacity. This review focuses on the ways to reduce stress and the effect of flavonoids, including quercetin, whose properties have been extensively studied in recent years, in order to increase the resistance of highly productive animals to various stress factors.
\end{abstract}

Keywords: Pigs; stress; nutrition; flavonoids; quercetins

Modern intensive technologies for handling and growing animals are associated with numerous conditions that do not correspond to their evolutionary physiology. Along with the focus on obtaining animals with genetically modified high productivity, this leads to intensification of the influence of stress factors and is accompanied by significant changes in the homeostasis, significantly affecting the quality of the final product (Plyashchenko \& Sidorov, 1983).

Stress is a combination of non-specific adaptive (normal) reactions of the body to the effects of various adverse factors, i.e. stressors (physical or psychological), violating its homeostasis, as well as the corresponding state of the nervous system (or the whole body). Hans Selye first introduced the concept of stress as "a non-specific response of the body to any change" (Selye, 1998). There are several stages of stress. The first stage is the stage of anxiety; it occurs immediately after the adverse effect takes place. The second stage is the stage of resistance; it is characterized by an increase in the body's resistance to the leading factor of adverse effect and other factors close to it. The third stage is the stage of exhaustion; it develops with the prolonged action of one or several stress factors, when the general and specific resistance of the organism decreases. Most often, the stages of stress development do not have clear boundaries (Danilkina, 2015). Depending on the cause, stress may be classified as social (technological), environmental, dietary, and immunological (Martinez-Miro et al., 2016).

Social or technological stress is observed during distribution into cages with unfamiliar animals, isolation, weaning, transportation, veterinary measure, etc. Exposure to social stress is always individual in nature and often associated with genetics, which has been confirmed by many studies (Zupan et al., 2017). Social stress may be acute, immediate after regrouping, or chronic when animals are kept in group cages or isolated, and also as a result of repeated regroupings (Coutellier et al., 2007). When animals are kept in larger groups, they are less exposed to social stresses. Increasing the density of animals in cages increases the likelihood of stress due to reduced access to feed and freedom of movement (Verdon et al., 2017). The authors showed that the frequency of social interactions and aggressive behavior increases as the density of sows increases (Remience et al., 2008), and the growth rate negatively correlates with the floor area per animal (Pereira et al., 2015). The authors note that the response to social stress is higher in males than in females (Holinger et al., 
2018). Thus, when studying the effect of technological stress on the body, higher levels of cortisol were observed even in the blood of castrates compared with gilts (Zupan et al., 2017).

One of the critical stages in the technology of growing pigs is the weaning period and their transfer to growing. In connection with the deprivation of maternal presence and milk, transfer to a new room, regrouping, and changing feed and staff, piglets experience technological stress. In this regard, the incidence of disease increases and a decrease in growth rates are noted. This reduces the resistance and indicators of humoral immunity, creates conditions for the activation of opportunistic microflora, which leads to indigestion or respiratory pathology (Danilevskaya et al., 2012). Dietary stress is the result of transfer from easily digestible maternal milk to solid feed based mainly on vegetable ingredients. Undigested protein enters the colon and becomes accessible to pathogenic bacteria that may cause inflammation and oxidative stress (Sirini \& Amarakoon, 2017). W. Dröge (2002) found that, under the influence of weaning stress, the level of cortisol in plasma increases significantly $(p<0.05)$, the expression of $c$-fos gene involved in many cellular functions, including the processes of cell growth regulation, is suppressed, and a decrease in corticotropin releasing hormone (CRH) is observed in the hypothalamus. In addition, the stress upon weaning increases the amount of c-jun mRNA and CRH receptor of the first type in the pituitary gland (Yu et al., 2019). Early weaning of piglets may significantly change the subsequent immune and physiological responses and clinical results upon subsequent infection with a pathogen (McLamb et al., 2013). The authors report that weaning of piglets causes both acute and prolonged structural and functional changes in the small intestine, including villous atrophy and lengthening crypt (Campbell et al., 2013), contributes to the inhibition of cellular processes in intestinal epithelial cells (Yang et al., 2016). The authors report a decrease in the level of lactase and aminopeptidase from 2nd to 15th day after weaning, while the activity of maltase decreases on the 2nd day after weaning, and then increases from 8th to 15th day after weaning. The activity of alkaline phosphatase, an enzyme that plays an important role in the detoxification of endotoxins, is also reduced in early-weaned piglets. These changes may affect the digestive and absorption capacity, the secretory capacity of the small intestine and, ultimately, the barrier function, which contributes to diarrhea after weaning (Campbell et al., 2013). In the authors' research, weaning caused changes in piglet blood, reflecting the stress response. Therefore, within 3 days after weaning, eosinopenia developed in animals with some neutrophilia (due to stab forms while reducing microxyphil ones). On the 3rd day, the piglets showed a 2.3-fold decrease in eosinophils and $11.0 \%$ decrease in lymphocytes (Vostroilova et al., 2015).

Transport stress is also a strong stress factor, and together with weaning stress it may negatively affect the health of piglets. This kind of stress may increase in animals when water consumption is restricted and/or blocked. Transportation has a particularly adverse effect on pig health when animals are not provided with water (Garcia et al., 2016; Garcia. Et al., 2015), and it is especially pronounced in adults (Averos et al., 2009). In gilts exposed to transport stress, higher levels of cortisol, albumin, glucose, total protein in the blood, and the ratio of granulocytes to lymphocytes were observed. Animals were more susceptible to physiological disturbances when transported for 6 hours compared to 12 to 30 hours, which indicates habituation (Sutherland, 2012). Short-term and prolonged noise effects increased the ratio of serum aspartate aminotransferase (AST) to alanine aminotransferase (ALT) and the levels of glucose, total bilirubin, cholesterol, urea, alkaline phosphatase, and a-amylase in pig blood, while total protein was reduced (Rapiyev \& Mannapova, 2013).

Intensification of pig industry requires constant environment monitoring, i.e., temperature, humidity, light, gas content (Pearce et al., 2013; Sanz Fernandez et al., 2015), and the environmental temperature should be optimal for each age and sex group (Wathes \& Whittemore, 2006). This is because pigs do not have sweat glands and thermoregulation is carried out only by breathing, so they can feel comfortable only in a very narrow temperature range (Klimenko \& Trukhin, 2012). The most significant changes resulted from heat stress occur in the cardiovascular, respiratory systems and the gastrointestinal tract. Heat stress negatively affects animal behavior, reduces feed intake (Baumgard \& Rhoads, 2013; Hao et al., 2014), affects growth rate (Pearce et al., 2013), leads to impaired reproductive ability, which is later onset of puberty, reducing the farrowing frequency (Jason et al., 2017; de Oliveira et al., 2019) and the number of live-born piglets (Wegner et al., 2016). Impaired perfusion of peripheral organs and tissues when exposed to high temperatures, first of all adversely affects pregnant sows, i.e. fetal nutrition decreases, embryonic mortality and abortions increase, especially at the early stages of pregnancy, parturation becomes difficult. Under the influence of heat stress, the production of adrenocorticotropic hormone and cortisol is stimulated, the production of thyroxin decreases, and insulin sensitivity increases. These physiological changes disturb the endocrine and energy balance in the body, leading to early embryo death, abortions and reduced milk production (Einarsson et al., 2008; Ross et al., 2015; Zeng et al., 2018). In addition, researchers note that the decrease in reproductive functions of sows under the influence of heat stress also depends on animal genotype (Bloemhof et al., 2014).

Exposure to heat stress during fetal development may permanently change postnatal phenotypes and adversely affect future animal productivity (Johnson et al., 2015), i.e. change the metabolic parameters of offspring and decrease the ratio of muscle to fatty tissue (Boddicker et al., 2014).

The decrease in feed intake is associated with the fact that during heat stress, the inhibition of secretory processes is triggered due to the redistribution of fluids as a result of increased water loss for the needs of thermoregulation. The secretion of gastric acid is inhibited and its bactericidal function becomes insufficient, while pepsin activity decreases and the concentration of total protein increases. The proteolytic enzymes, i.e. pepsin, trypsin, enterokinase, is subjected to the most significant inhibition, as a result of which the rate of amino acid absorption decreases. Inhibition of pancreatic enzyme secretion occurs, and intestinal motility decreases (Klimenko \& Trukhin, 2012).

Researchers have noted changes in the direction of lipid and carbohydrate metabolism in the body under the influence of heat stress (Sanz Fernandez et al., 2015), while insulin sensitivity and glucose uptake increase (Febbraio, 2001; Maciver et al., 2008; Sanz Fernandez et al., 2015). Constant heat exposure reduces digestibility of dry matter and protein, with an increase in rectal temperature and respiratory rate (Pearce et al., 2013; Hao et al., 2014; Johnson et al., 2015). The plasma levels of 
cortisol, creatine kinase and lactate dehydrogenase significantly increase (Hao et al., 2014), as well as insulin concentration (Pearce et al., 2013). Adverse effects of heat stress become more severe when it is combined with various technological stresses (regrouping, weaning, isolation, veterinary activities) (Johnson et al., 2019).

Metabolic (dietary) stress is a result of restricted or blocked access to food and/or water (Ott et al., 2014). The adverse effects of metabolic stress depend on the length of fasting period. At the same time, the level of glucose in the blood decreases and the metabolism changes from anabolic to catabolic. In order to overcome this, non-esterified fatty acids (NEFA), betahydroxybutyrate, and glycerin are used in the body to meet energy needs. Moreover, these compounds may be used as markers of metabolic stress in animals.

When changing from anabolic to catabolic metabolism, metabolic stress in sows during late pregnancy and high milk production may also provoke oxidative stress (Pshennikova, 2000). The resulting free-radical oxidation end products are highly toxic compounds that damage the cells of tissues and organs, change the physical and biological properties of the membranes, disintegrate oxidative phosphorylation and disturb the ion pumps in membranes (Menshikova, 2006). Freeradical oxidation is reduced in the presence of antioxidants: this explains their action as lipid peroxidation inhibitors (Gusev \& Panchenko, 1982). Oxidative stress accompanied by damage to mitochondrial DNA is the cause of many pathologies: diabetes with retinopathy, muscular dystrophy, cardiomyopathy, etc. (Kamyshnikov, 2003).

With chronic exposure to various stressful situations, activation of free-radical oxidation occurs with simultaneous depletion of antioxidant defense. In the body, syndromes of maladaptation, ketosis, hepatic dystrophy, and autoimmune processes are observed (Minotti \& Aust, 1989).

It is known that the use of antioxidants in animal diets contributes to the stabilization of free radicals (Tolkushkina, 2001; Cadenas \& Packer, 2002). Many plants, including vegetables and spices, contain natural antioxidants and are widely studied by researchers (Sebranek et al., 2005; Mariassyova, 2006; Carpenter et al., 2007; Habanova \& Haban, 2008).

Some plant extracts contain flavonoids and phenolic ingredients that have antioxidant effects. In studies of S. Sekretar et al. (2018), extracts of burdock, black tea, rosemary and sage were the most effective. Extracts with good antioxidant activity also showed antimicrobial efficacy. Other studies show that a mixture of natural antioxidants based on plant extracts and vitamin E added to pig diets at concentrations of $271.2 \mathrm{mg} / \mathrm{kg}$ and $90.4 \mathrm{mg} / \mathrm{kg}$, respectively, can effectively protect pig's lymphocytes from oxidative damage to DNA, thus suggesting their potentially beneficial effects on the immune system during diet-induced oxidative stress (Frankič et al., 2010).

Shaposhnikov et al. (2016) studied the effect of plant-based preparation containing phytoecdysteroids or steroid glycosides on the expression of stress response genes and stress resistance. Plant-based preparation have been showed to activate the mechanisms of antioxidant protection, have adaptogenic and geroprotective effects associated with the activation of hormonal mechanisms. Recently, the use of flavonoids, in particular quercetin, has become widespread. Flavonoids are secondary plant metabolites exhibiting a wide range of pharmacological and biological activities. Among the flavonoids, quercetin received a special attention from researchers (Lucio et al., 2016).

Dihydroquercetin $\left(\mathrm{C}_{15} \mathrm{H}_{12} \mathrm{O}_{7}\right)$ is the main component of the Diquertin bioflavonoid complex. Dihydroquercetin is a bioflavonoid with a wide range of biological effects: it regulates metabolic processes, has a positive effect on the functional state of the internal organs, creates mechanisms for protecting healthy cells from pathologies caused by chemical toxicity, electromagnetic emission and radiation, by eliminating radical activity, viral and bacterial processes. It is non-toxic, harmless, highly active at low concentrations, and resistant to thermal and mechanical exposure. Dihydroquercetin is recognized as a reference antioxidant and is widely used in medicine and food industry.

A large amount of information has been accumulated about the detection of dihydroquercetin in the composition of phenolic mixtures from many herbaceous and shrubby plants. Some of the studied plants are of interest as potential medicinal herbs, for example, knotweed (Polygonum nodosum Pers.), leaves and stems of buckthorn (Rhamnus lycioides L.), while some plants are already known and widely used in medical practice, such as milk thistle. The fruits of milk thistle (Silybum marianum (L.) Gaertn.) containing dihydroquercetin and its 3-methyl ester (silimarin) along with flavolignins, are used as raw materials for the preparation of hepatoprotective drug, Siliborum (analogue of Legalon and Carsil).

Dihydroquercetin is found in some edible plants, i.e. citrus fruits, cotton and sorghum seeds, peanuts (Arachis hypogaea L.). It is believed that the protection of peanut oils ( $40 \%$ to $60 \%)$ is provided by dihydroquercetin.

As a result of many years of research, Siberian larch wood and Dahurian larch wood were chosen as a raw material for industrial dihydroquercetin production (Fomichev et al., 2011; Nikanova \& Fomichev, 2012).

When using dihydroquercetin in pig nutrition, inhibition of lipid peroxidation process was observed during the entire period of growing and fattening. Thus, acid and peroxide values, malonic aldehyde in the serum of piglets from the experimental group were lower than in the control group, and the antioxidant defense was higher, which was expressed in an increase in the antioxidant activity of plasma. At the same time, a decrease in the area of myocardial cardiomyocytes was observed in experimental animals as compared with the control ones. These changes indicate a lower physiological stress of the cardiovascular system, which is the result of increased resistance to stressful situations resulted in stabilization of potassiummagnesium ratio and, subsequently, normalization of blood pressure (Fomichev et al., 2017; Spinul, 2018).

The addition of dihydroquercetin ( $50 \mathrm{mg} / \mathrm{animal} /$ day) in piglet diet in the post-weaning period significantly weaken the effect of stressful environmental factors and increased their adaptive capacity; as a result, the average daily gain in the postweaning period was $496 \mathrm{~g} /$ day, which was $20.6 \%$ higher compared to the control group (Nikanova et al., 2017). The authors (Fomichev et al., 2017; Nikanova et al., 2017) recommended the use of dihydroquercetin bioflavonoid at $1.5 \mathrm{mg} / \mathrm{kg}$ BW/day in order to provide antioxidant, immunomodulatory and adaptogenic properties in pig diets. The use of this supplement in pig nutrition inhibited free-radical oxidation of lipids, increased antioxidant protection and the functional state of the liver during 
the entire period of growing and fattening. This helped to intensify anabolic processes. As a result, pigs in the experimental group had $20 \%$ higher average daily gain during the entire period of growing and fattening, and especially during extremely high temperatures.

In another experiment, the authors studied the effect of quercetin supplementation on the intestine function, the level of reactive oxygen species (ROS) in the intestine and intestine inflammation in pigs upon transport stress. Quercetin helped to reduce the manifestations of oxidative stress and inflammation in the intestine of animals, which was confirmed by lower levels of intestinal ROS and malonic dialdehyde (MDA), a decrease in serum endotoxin, an increase in the height of the jejunum villi (Zou et al., 2016).

The effect of new nine dihydroquercetin (taxifolin) derivatives on the viability of cultured normal and tumor cells, their antioxidant activity and the relationship of antioxidant activity to the chemical structure were studied. The maximum total antioxidant activity was observed for native dihydroquercetin and KN-8 compound (Rogovskii et al., 2010). A range of new 3mono-acylated dihydroquercetin derivatives were synthesized and had antioxidant and cytotoxic activity against tumor cells (Knyazev et al., 2018).

\section{Conclusion}

Thus, stressful situations associated with the technology of animal growing and fattening, environmental and other factors negatively affect the animal health, as well as the quality of the products obtained from these animals. In recent years, various antemortem and postmortem pathological changes in the muscle tissue microstructure of farm animals and poultry, which are associated with stress factors, has been observed. The affected structures of muscle fibers are characterized by hyper contraction, disruption of cell membranes, lysis of nuclei and cell organelles with formation of extracellular protein substance represented by denatured forms of proteins not participating in the formation of nutritional matrix of the final product with the required characteristics.

According to foreign researchers (INRA, France), in European countries the proportion of produced pig carcasses with similar changes in muscle tissue microstructure is more than $17 \%$. The solution to this problem is possible only with a complex of activities, including the use of nutritional factors. One of the ways is the use of antioxidants, as well as natural bioflavonoids. Modern scientists have shown the positive effect of using natural antioxidants in diets on the quality of meat from monogastric animals (Janz et al., 2007; Moroney et al., 2012). The use of antioxidants in meat production is an effective way to minimize the development of oxidative rancidity, extend the shelf life and increase nutritional quality (Gupta \& Abu-Ghannam, 2011).

The use of natural antioxidants and their complexes in pig diets contributed to an increase in lipid and meat color stability after 5-day storage of pork (Lahucky et al., 2010). Thus, we believe that further studies are needed concerning the use of natural antioxidants in feeding the intensively growing pigs to reduce stress effects, particularly on the quality of meat products and the severity of hypercontraction and autolysis of muscle fibers in fattened pigs.

\section{Acknowledgements}

The work was supported by the grant No. 19-16-00068 of the Russian Science Foundation.

\section{References}

Averós, X., Herranz, A., Sánchez, R., \& Gosálvez, L. F. (2009). Effect of the duration of commercial journeys between rearing farms and growing-finishing farms on the physiological stress response of weaned piglets. Livestock Science, 122(2-3), 339344. doi: https://doi.org/10.1016/j.livsci.2008.09.019.

Baumgard, L. H., \& Rhoads Jr, R. P. (2013). Effects of heat stress on postabsorptive metabolism and energetics. Annu. Rev. Anim. Biosci., 1(1), 311-337. doi: https://doi.org/10.1146/annurev-animal-031412-103644.

BloEMhoF, S., Van der Waaij, E. H., Merks, J. W. M., \& Knol, E. F. (2008). Sow line differences in heat stress tolerance expressed in reproductive performance traits. Journal of Animal Science, 86(12), 3330-3337. doi: https://doi.org/10.2527/jas.2008-0862. Boddicker, R. L., Seibert, J. T., Johnson, J. S., Pearce, S. C., Selsby, J. T., Gabler, N. K., Lucy, M. C., Safranski, T. J., Rhoads, R. P., Baumgard, L. H. \& Ross, J. W. (2014). Gestational heat stress alters postnatal offspring body composition indices and metabolic parameters in pigs. PLoS ONE, 9(11), e110859. doi: https://doi.org/10.1371/journal.pone.0110859.

Cadenas, E. \& Packer, L. (2002). Handbook of antioxidants: second edition, revised and expanded. New York: Marcel Dekker. Campbell, J. M., Crenshaw, J. D., \& Polo, J. (2013). The biological stress of early weaned piglets. Journal of animal science and biotechnology, 4(1), 19. doi: https://doi.org/10.1186/2049-1891-4-19.

Carpenter, R., O'grady, M. N., O'callaghan, Y. C., O'brien, N. M., \& Kerry, J. P. (2007). Evaluation of the antioxidant potential of grape seed and bearberry extracts in raw and cooked pork. Meat science, 76(4), 604-610. doi: https://doi.org/10.1016/j.meatsci.2007.01.021.

Costa, L. G., Garrick, J. M., Roquè, P. J., \& Pellacani, C. (2016). Mechanisms of neuroprotection by quercetin: counteracting oxidative stress and more. Oxidative medicine and cellular longevity, Article ID 298679610 , 10 p. http://dx.doi.org/10.1155/2016/2986796.

Coutellier, L., Arnould, C., Boissy, A., Orgeur, P., Prunier, A., Veissier, I., \& Meunier-Salaün, M. C. (2007). Pig's responses to repeated social regrouping and relocation during the growing-finishing period. Applied Animal Behaviour Science, 105(1-3), 102-114. doi: https://doi.org/10.1016/j.applanim.2006.05.007. 
de Oliveira, A. C. D. F., Vanelli, K., Sotomaior, C. S., Weber, S. H., \& Costa, L. B. (2019). Impacts on performance of growingfinishing pigs under heat stress conditions: a meta-analysis. Veterinary research communications, 43(1), 37-43. doi: https://doi.org/10.1007/s11259-018-9741-1.

Danilevskaya, N. V., \& Tukhfatova, N. F. (2012). Ispolzovaniye metoda selektivnoy dekontaminatsii pri otyeme porosyat. Agrarnyy vestnik Urala, 5, 36-39 (in Russian).

Danilkina, O. P. (2015). Fiziologiya stressa: metodicheskiye ukazaniya. Krasnoyarsk (in Russian).

Dröge, W. (2002). Free radicals in the physiological control of cell function. Physiol Rev, 82(1), 47-95. doi: https://doi.org/10.1152/physrev.00018.2001.

Einarsson, S., Brandt, Y., Lundeheim, N., \& Madej, A. (2008). Stress and its influence on reproduction in pigs: a review. Acta Veterinaria Scandinavica, 50(1), 48. doi: https://doi.org/10.1186/1751-0147-50-48.

Febbraio, M. A. (2001). Alterations in energy metabolism during exercise and heat stress. Sports medicine, 31(1), 47-59. doi: https://doi.org/10.2165/00007256-200131010-00004.

Fomichev, Yu. P., Nikanova, L. A., \& Netecha, Z. A. (2011). Bioprotektornoye deystviye digidrokvertsetina i arabinogalaktana v oslablenii ekstremalnykh effektov sredy na organizm zhivotnykh. Vetkorm, 4, 30-31 (in Russian).

Fomichev, Yu. P., Nikanova, L. A., Dorozhkin, V. I., Torshkov, A. A., Romanenko, A. A., Es'kov, E. K., Semenova, A. A., Gonockij, V. A., Dunaev, A. V., YAroshevich, G. S., Lashin, S. A., \& Stol'naya, N. I. (2017). Digidrokvercetin i arabinogalaktan - prirodnye bioregulyatory $v$ zhiznedeyatel'nosti cheloveka i zhivotnyh, primenenie $v$ sel'skom hozyajstve i pishchevoj promyshlennosti. Moskva. Nauchnaya biblioteka (in Russian).

Frankič, T., Levart, A., \& Salobir, J. (2010). The effect of vitamin E and plant extract mixture composed of carvacrol, cinnamaldehyde and capsaicin on oxidative stress induced by high PUFA load in young pigs. Animal, 4(4), 572-578. doi: https://doi.org/10.1017/S1751731109991339.

Garcia, A., Sutherland, M., Pirner, G., Picinin, G., May, M., Backus, B., \& McGlone, J. (2016). Impact of providing feed and/or water on performance, physiology, and behavior of weaned pigs during a 32-h transport. Animals, 6(5), 31. doi: https://doi.org/10.3390/ani6050031.

Garcia, A., Pirner, G., Picinin, G., May, M., Guay, K., Backus, B., Sutherl, M. \& McGlone, J. (2015). Effect of provision of feed and water during transport on the welfare of weaned pigs. Animals, 5(2), 407-425. doi: https://doi.org/10.3390/ani5020363.

Gupta, S., \& Abu-Ghannam, N. (2011). Recent developments in the application of seaweeds or seaweed extracts as a means for enhancing the safety and quality attributes of foods. Innovative Food Science \& Emerging Technologies, 12(4), 600-609. doi: https://doi.org/10.1016/j.ifset.2011.07.004.

Gusev, V. A., \& Panchenko, L. F. (1982). Superoksidnyy radikal i superoksiddismutaza v svobodnoradikalnoy teorii stareniya. Voprosy meditsinskoy khimii, 28(4), 8-25 (in Russian).

Habanova, M., \& Haban, M. (2008). Evaluation of antiradical activity of chosen plant resources. Acta Fytotechnica et Zootechnica, 1, 21-24.

Hao, Y., Feng, Y., Yang, P., Feng, J., Lin, H., \& Gu, X. (2014). Nutritional and physiological responses of finishing pigs exposed to a permanent heat exposure during three weeks. Archives of animal nutrition, 68(4), 296-308. doi: https://doi.org/10.1080/1745039X.2014.931522.

Holinger, M., Früh, B., Stoll, P., Graage, R., Wirth, S., Bruckmaier, R., Prunier, A., Kreuzer, M., \& Hillmann, E. (2018). Chronic intermittent stress exposure and access to grass silage interact differently in their effect on behavior, gastric health and stress physiology of entire or castrated male growing-finishing pigs. Physiology \& Behavior, 195, 58-68. doi: https://doi.org/10.1016/j.physbeh.2018.07.019.

Janz, J. A. M., Morel, P. C. H., Wilkinson, B. H. P., \& Purchas, R. W. (2007). Preliminary investigation of the effects of low-level dietary inclusion of fragrant essential oils and oleoresins on pig performance and pork quality. Meat Science, 75(2), 350-355. doi: https://doi.org/10.1016/j.meatsci.2006.06.027.

Johnson, J. S., \& Baumgard, L.H. (2019). Physiology symposium: postnatal consequences of in utero heat stress in pigs. Journal of Animal Science, 97(2), 962-971. doi: https://doi.org/10.1093/jas/sky472.

Johnson, J. S., Abuajamieh, M., Sanz Fernandez, M. V., Seibert, J. T., Stoakes, S. K., Nteeba, J., \& Baumgard, L. H. (2015). Thermal stress alters postabsorptive metabolism during pre- and postnatal development. Book Chapter: Thermal Stress Alters Postabsorptive Metabolism During Pre- and Postnatal Development, 61-80. doi: https://doi.org/10.1007/978-81-322-2265-1 5. Johnson, J. S., Sanz Fernandez, M. V., Gutierrez, N. A., Patience, J. F., Ross, J. W., Gabler, N. K., \& Baumgard, L. H. (2015). Effects of in utero heat stress on postnatal body composition in pigs: I. Growing phase. Journal of Animal Science, 93(1), 71-81. doi: https://doi.org/10.2527/jas.2014-8354.

Kamyshnikov, V. S. (2003). Sistema perekisnoye okisleniye lipidov - antioksidantnaya zashchita organizma. Klinikobiokhimicheskaya laboratornaya diagnostic. Sainct Petersburg (in Russian).

Klimenko, A. S., \& Trukhin, D. A. (2012). Teplovoy stress u sviney i ego profilaktika. Svinovodstvo, 2, 31 -32 (in Russian).

Knyazev, V. V., Rogovskii, V. S., Sveshnikova, E. D., Semeikin, A. V., Matyushin, A. I., Fedotcheva, T. A., Shimanovskii, N. L., Pozdeev, A. O., Koroteev, A. M., \& Koroteev, M. P. (2018). Synthesis and Antioxidant and Cytotoxic Activity of New Dihydroquercetin Derivatives. Pharmaceutical Chemistry Journal, 52(3), 205-208. Doi: https://doi.org/10.1007/s11094-018$1791-8$

Lahucky, R., Nuernberg, K., Kovac, L., Bucko, O., \& Nuernberg, G. (2010). Assessment of the antioxidant potential of selected plant extracts - in vitro and in vivo experiments on pork. Meat Science, 85(4), 779-784. doi: https://doi.org/10.1016/j.meatsci.2010.04.004 
Costa, L. G., Garrick, J. M., Roquè, P. J., \& Pellacani, C. (2016). Mechanisms of neuroprotection by quercetin: counteracting oxidative stress and more. Oxidative medicine and cellular longevity, Article ID $2986796 . \quad$ Doi: https://doi.org/10.1155/2016/2986796.

Maclver, N. J., Jacobs, S. R., Wieman, H. L., Wofford, J. A., Coloff, J. L., \& Rathmell, J. C. (2008). Glucose metabolism in lymphocytes is a regulated process with significant effects on immune cell function and survival. Journal of leukocyte biology, 84(4), 949-957. doi: https://doi.org/10.1189/jlb.0108024.

Mariassyova, M. (2006). Antioxidant activity of some herbal extracts in rapeseed and sunflower oils. Journal of Food and Nutrition Research, 45(3), 104-109.

Martínez-Miró, S., Tecles, F., Ramón, M., Escribano, D., Hernández, F., Madrid, J., Orengo, J., Martinez-Subiela, S., Manteca, X. \& Cerón, J. J. (2016). Causes, consequences and biomarkers of stress in swine: an update. BMC Veterinary Research, 12, 171. doi: https://doi.org/10.1186/s12917-016-0791-8.

McLamb, B. L., Gibson, A. J., Overman, E. L., Stahl, C., \& Moeser, A. J. (2013). Early weaning stress in pigs impairs innate mucosal immune responses to enterotoxigenic E. coli challenge and exacerbates intestinal injury and clinical disease. PloS one, 8(4), e59838. doi: https://doi.org/10.1371/journal.pone.0059838.

Menshikova, E .B. (2006). Okislitelnyy stress. Prooksidanty i antioksidanty. Moskva: Firma "Slovo" (in Russian).

Minotti, G., \& Aust, S. D. (1989). The role of iron in oxygen radical mediated lipid peroxidation. Chemico-biological interactions, 71(1), 1-19.

Moroney, N. C., O'Grady, M. N., O'Doherty, J. V., \& Kerry, J. P. (2012). Addition of seaweed (Laminaria digitata) extracts containing laminarin and fucoidan to porcine diets: Influence on the quality and shelf-life of fresh pork. Meat science, 92(4), 423-429. doi: https://doi.org/10.1016/j.meatsci.2012.05.005.

Nikanova, L. A., Fomichev, Yu. P., \& Narizhnyy, A. G. (2017). Primeneniye digidrokvertsetina antioksidanta i arabinogalaktana prebiotika v svinovodstve: Rukovodstvo. Dubrovitsy: VIZh im. L.K. Ernsta (in Russian).

Nikanova, L. A., \& Fomichev, Yu. P. (2012). Rol kormovykh dobavok v oslablenii ekologi4545cheskogo temperaturnogo stressa u sviney. Rossiyskiy zhurnal. Problemy veterinarnoy sanitaria, gigiyeny i ekologii, 1(7), 62-65 (in Russian).

Ott, O., Soler, L., Moons, C. P. H., Kashiha, M. A., Bahr, C., Vandermeulen, J., Janssens, S., Gutiérrez, A. M., Escribano, D, Cerón, J. J., Berckmans, D., \& Tuyttens, F. A. M. (2014). Different stressors elicit different responses in the salivary biomarkers cortisol, haptoglobin, and chromogranin A in pigs. Res Vet Sci, 97, 124-128. doi: https://doi.org/10.1016/j.rvsc.2014.06.002.

Pearce, S. C., Gabler, N. K., Ross, J. W., Escobar, J., Patience, J. F., Rhoads, R. P., \& Baumgard, L. H. (2013). The effects of heat stress and plane of nutrition on metabolism in growing pigs. Journal of animal science, 91(5), 2108-2118. doi: https://doi.org/10.2527/jas.2012-5738.

Pereira, T. L., Corassa, A., Komiyama, C. M., Araújo, C. V., \& Kataoka, A. (2015). The effect of transport density and gender on stress indicators and carcass and meat quality in pigs. Spanish Journal of Agricultural Research, 13(3), 0606. doi: https://doi.org/10.5424/sjar/2015133-6638.

Plyashchenko, S. I. \& Sidorov, V. T. (1983). Preduprezhdeniye stressov u selskokhozyaystvennykh zhivotnykh. Minsk. Uradzhay (in Russian).

Pshennikova, M. G. (2000). Fenomen stressa. Emocional'nyj stress i ego rol' v patologii (prodolzhenie). Patologicheskaya fiziologiya i eksperimental'naya terapiya, 4, 21-31(in Russian).

Rapiyev, R. A., \& Mannapova, R. T. (2013). Biokhimicheskiy status organizma zhivotnykh kak kompensatorno-regulyatornaya reaktsiya na fone deystviya stressa. Fundamentalnyye issledovaniya, 10-12, 2663-2666 (in Russian).

Remience, V., Wavreille, J., Canart, B., Meunier-Salau, M. C., Prunier, A., Bartiaux-Thill, N., Nicks, B., \& Vandenheede, M. (2008). Effects of space allowance on the welfare of dry sows kept in dynamic groups and fed with an electronic sow feeder. Appl Anim Behav Sci, 112, 284-296. doi: https://doi.org/10.1016/j.applanim.2007.07.006.

Rogovskii, V. S., Matyushin, A. I., Shimanovskii, N. L., Semeikin, A. V., Kukhareva, T. S., Koroteev, A. M., Koroteev, M. P., \& Nifant'ev, E. E. (2010). Antiproliferative and antioxidant activity of new dihydroquercetin derivatives. Eksperimental'naya i Klinicheskaya Farmakologiya, 73(9), 39-42 (in Russian).

Ross, J. W., Hale, B. J., Gabler, N. K., Rhoads, R. P., Keating, A. F., \& Baumgard, L. H. (2015). Physiological consequences of heat stress in pigs. Animal Production Science, 55(12), 1381-1390. doi: https://doi.org/10.1071/AN15267.

Ross, J. W., Hale, B. J., Seibert, J. T., Romoser, M. R., Adur, M. K., Keating, A. F., \& Baumgard, L. H. (2017). Physiological mechanisms through which heat stress compromises reproduction in pigs. Molecular reproduction and development, 84(9), 934-945. doi: https://doi.org/10.1002/mrd.22859.

Victoria Sanz Fernandez, M., Johnson, J. S., Abuajamieh, M., Stoakes, S. K., Seibert, J. T., Cox, L., Kahl, S., Elsasser, T. H., Ross, J. W., Isom, S. C., Rhoads, R. P., \& Baumgard, L. H. (2015). Effects of heat stress on carbohydrate and lipid metabolism in growing pigs. Physiology Reproduction, 3(2), e12315. doi: https://doi.org/10.14814/phy2.12315.

Sanz Fernandez, M. V., Stoakes, S. K., Abuajamieh, M., Seibert, J. T., Johnson, J. S., Horst, E. A., Rhoads, R. P., \& Baumgard, L. H. (2015). Heat stress increases insulin sensitivity in pigs. Physiol Rep, 3(8), e12478. https://doi.org/10.14814/phy2.12478

Sebranek, J. G., Sewalt, V. J., Robbins, K. L., \& Houser, T. A. (2005). Comparison of a natural rosemary extract and BHA/BHT for relative antioxidant effectiveness in pork sausage. Meat Science, 69, $289-296.2$ doi: https://doi.org/10.1016/j.meatsci.2004.07.010.

Sekretar, S., Schmidt, S., Vajdak, M., Zahradnikova, L., \& Annus, J. (2018). Antioxidative and antimicrobial effects of some natural extracts in lard. Czech Journal of Food Sciences, 22, 215-218. doi: https://doi.org/10.17221/10664-CJFS.

Selye, H. (1998) Syndrome produced by diverse nocuous agents. 1936. J Neuropsychiatry Clin Neurosci, 10(2), 230-1138. doi: https://doi.org/10.1176/jnp.10.2.230a 
Shaposhnikov, M. V., Shilova, L. A., Plyusnina, E. N., Volodina, S. O., Volodin, V. V., \& Moskalev, A. A. (2016). Influence of preparations containing phytoecdysteroids and plant steroid glycosides on the life span and stress resistance of Drosophila melanogaster. Russian Journal of Genetics: Applied Research, 6(2), 215-222 (in Russian).

Sirini, A. M., Amarakoon, B. K. Regulation of oxidative stress in weaned piglets challenged with Escherichia coli. (2017). A Thesis submitted to Faculty of Graduate studies of The University of Manitoba in fulfillment of the requirements of the degree of Master of Science Department of Animal Science Faculty of Agricultural and Food Sciences University of Manitoba, Winnipeg, Manitoba, Canada. Available from: http://hdl.handle.net/1993/32492/.

Spinul, A. I. (2018). Fiziologicheskie aspekty profilaktiki i metafilaktiki narushenij obmena veshchestv i snizheniya rezistentnosti organizma telyat $v$ molochnyj period vyrashchivaniya. Thesis of Doctoral Dissertation. FGBNU "Federal'nyj nauchnyj centr zhivotnovodstva - VIZH imeni akademika L.K. Ernsta" (in Russian).

Sutherland, M. A., Bryer, P. J., Davis, B. L., Smith, J. F., \& McGlone, J. J. (2012). The combined effects of transport and food and water deprivation on the physiology of breeding age gilts. Livestock science, 144(1-2), 124-131. doi: https://doi.org/10.1016/j.livsci.2011.11.005.

Tolkushkina, G. D. (2001). Sistema antioksidantnoy zashchity zhivotnykh pri khronicheskikh antropogennykh nagruzkakh: teoreticheskiye predposylki. Selskoye khozyaystvo Sibiri na rubezhe vekov: Itogi i perspektivy razvitiya. Novosibirsk (in Russian).

Verdon, M., Hansen, C. F., Rault, J. L., Jongman, E., Hansen, L. U., Plush, K., \& Hemsworth, P. H. (2015). Effects of group housing on sow welfare: a review. Journal of Animal Science, 93(5), 1999-2017. doi: https://doi.org/10.2527/jas.2014-8742.

Vostroilova, G. A., Khokhlova, N. A., Lobodina, T. E., Fomenko, O. Yu., Alekhin, Yu. N., \& Mikhaylov, E. V. (2015). Biokhimicheskiy i immunnyy status porosyat pri otyemnom stresse i ego farmakokorrektsiya aminoseletonom. Veterinarnaya patologiya, 1(51), 69-75 (in Russian).

Wathes, C., \& Whittemore, C. (2006). Environmental management of pigs. In: Kyriazakis I., Whittemore C., Whittemore C.T. (Eds.). Whitemore's science and practice of pig production. Oxford: Blackwell Publishing, pp: 533-590.

Wegner, K., Lambertz, C., Das, G., Reiner, G., \& Gauly, M. (2016). Effects of temperature and temperature- humidity index on the reproductive performance of sows during summer months under a temperate climate. Animal Science Journal, 87(11), 1334-1339. doi: https://doi.org/10.1111/asj.12569.

Yang, H., Xiong, X., Wang, X., Tan, B., Li, T., \& Yin, Y. (2016). Effects of weaning on intestinal upper villus epithelial cells of piglets. PloS one, 11(3), e0150216. doi: https://doi.org/10.1371/journal.pone.0150216.

Yu, C. H., Chen, C. Y., \& Chang, C. C. (2019). The immediate effects of weaning stress on the hypothalamus- pituitary- adrenal alteration of newly weaned piglets. Journal of animal physiology and animal nutrition. doi: https://doi.org/10.1111/jpn.13104.

Zeng, Y., Wang, H., Liu, Z., Li, S., Pu, S. \& Long, D. (2018). Effects of ambient temperature on production performance of sows and regulatory techniques. Scientia Agricultura Sinica, 51(16), 3171-3180. doi: https://doi.org/10.3864/j.issn.05781752.2018.16.013.

Zou, Y., Wei, H. K., Xiang, Q.-H., Wang, J., Zhou, Y.-F., \& Peng, J. (2016). Protective effect of quercetin on pig intestinal integrity after transport stress is associated with regulation oxidative status and inflammation. J Vet Med Sci, 78(9), 1487-1494. doi: https://doi.org/10.1292/jvms.16-0090.

Zupan, M., \& Zanella, A. J. (2017). Peripheral regulation of stress and fear responses in pigs from tail-biting pens. Revista Brasileira de Zootecnia, 46(1), 33-38. doi: https://doi.org/10.1590/S1806-92902017000100006.

Citation: Bogolyubova, N.V., Chabaev, M.G., Fomichev, Yu.P., Tsis, E.Yu., Semenova, A.A., Nekrasov, R.V. (2019). Ways to reduce adverse effects of stress in pigs using nutritional factors. Ukrainian Journal of Ecology, 9(2), 239-245.

(cc) EY This work is licensed under a Creative Commons Attribution 4.0. License 